\title{
POTASSIUM CHANNELS OPENER PINACIDIL HAVE MULTIPLE EFFECTS ON KCI-ELICITED CONTRACTIONS OF ISOLATED NON-PREGNANT RAT UTERUS
}

\author{
NOVAKOVIĆ RADMILA*, MILOVANOVIĆ $\mathrm{S}^{* *}$, ĆUPIĆ $\mathrm{V}^{* * *}$ and GOJKOVIĆ-BUKARICA LJILJANA* \\ *University of Belgrade, Faculty of Medicine, Serbia \\ **University of East Sarajevo, Faculty of Medicine, Foca, Federation BH \\ $* * *$ University of Belgrade, Faculty of Veterinary Medicine, Serbia \\ (Received 27th April 2010)
}

The effects of $K^{+}$channel opener, pinacidil on contractions provoked by contraction-stimulating $\mathrm{KCl}$ were investigated on isolated uterus of non-pregnant rats in oestrus. Pinacidil produced a more potent inhibition of $20 \mathrm{mM} \mathrm{KCl-elicited} \mathrm{contractions}\left(p D_{2}=6.57 \mu \mathrm{M}\right)$ than of 40 or $80 \mathrm{mM} \mathrm{KCl}$-elicited contractions $\left(p \mathrm{D}_{2}=5.11\right.$ and $5.19 \mu \mathrm{M}$, respectively). Glibenclamide, a selective blocker of adenosine triphosphate (ATP)-sensitive $K^{+}\left(K_{\text {ATP }}\right)$ channels, antagonized the pinacidil-induced inhibition of contractions elicited by $20 \mathrm{mM} \mathrm{KCl}$ in a competitive manner. However, the pinacidil-induced inhibition of contractions provoked by 40 and $80 \mathrm{mM} \mathrm{KCl}$ glibenclamide was unable to prevent them. Pinacidil ability to completely relax the non-pregnant uterus pre-contracted with $\mathrm{K}^{+}$-rich solution suggests that $\mathrm{K}^{+}$channelindependent mechanism(s) also plays a part in its relaxant effect.

Key words: high $\mathrm{K}^{+}$solution, $\mathrm{K}_{\mathrm{ATP}}$ channels, pinacidil, rat uterus

\section{INTRODUCTION}

Contractions of smooth muscles are regulated by the intracellular $\mathrm{Ca}^{2+}$ level, and the sensitivity to $\mathrm{Ca}^{2+}$ of the contractile elements in response to changes in the environment surrounding the cell. Uterine contractile activity is determined by the increase in intracellular free $\mathrm{Ca}^{2+}$ concentration in the myometrial cells. Potassium channels $\left(\mathrm{K}^{+}\right.$channels) activation has an inhibitory effect on uterine contractile activity through hyperpolarization by changing the membrane potential away from the threshold required to generate an action potential of myometrial cells.

The numerous physiological mechanisms that control uterus contractility by involving the modulation of ion currents have led to the elaboration and investigation of various therapeutic methods.

Pinacidil is an antihypertensive agent, which can relax various smooth muscles (Davies et al., 1996; Gojkovic and Kazic, 1999; Gojkovic-Bukarica et al., 2010), including the animal (Piper et al., 1990; Mandi et al., 2005; Novakovic et al., 2007) and human uterus (Morrison et al., 1993, Khan et al., 1998). The mechanism 
of action has not yet been fully established, but has been named that relaxation responses are associated with the opening of $\mathrm{K}^{+}$channels and characterized by its ability to cause cell hyperpolarization by primarily increasing potassium ion permeability (Bray et al., 1987).

The aim of this study was to determine the relaxant properties of pinacidil on contractions provoked with contraction-stimulant $\mathrm{KCl}$ on the isolated uterus of non-pregnant rats and their sensitivity to glibenklamide, a potent blocker of adenosine 5 -triphosphate - sensitive potassium channels ( $\left.\mathrm{K}_{\text {ATP }}\right)$.

\section{MATERIALS AND METHODS}

\section{General Methods or Tissue Preparation}

Experiments were carried out on virgin female Wistar rats weighing 200 $250 \mathrm{~g}$. This investigation conforms to the principles outlined in the "Good Laboratory Practice" and was approved by the Medical Ethics Committee of the Military Medical Academy. Rats were pretreated 24h before the experiment with $17 \beta$-oestradiol benzoate $(100 \mu \mathrm{g} / \mathrm{kg}$, i.p.) according to the method of Hughes and Hollingsworth (1995). Uterine horns were cut into longitudinal segments approximately $1 \mathrm{~cm}$ long and mounted in a $10 \mathrm{~mL}$ organ chamber containing PSS. The temperature in the organ bath was maintained at $30^{\circ} \mathrm{C}$ and the solution was continuously aerated with $95 \% \mathrm{O}_{2}$ and $5 \% \mathrm{CO}_{2}(\mathrm{pH} \sim 7.4)$. Strips were equilibrated at passive tension of $1 \mathrm{~g}$ for $1 \mathrm{~h}$. Isometric tension was measured with isometric force transducer "K 30, Hugo Sachs" (Freiburg, Germany) and recorded on a 2channel recorder "R60, Rikadenki" (Tokyo, Japan). The mechanical responses were measured as integrated tension by the method of Granger et al. (1985).

\section{Experimental procedure}

After equilibration, uterus strips were stimulated with $\mathrm{KCl}(20,40,80 \mathrm{mM})$ to induce contraction and allowed a 60 min period to assess the control contractile performance. On each strip only one $\mathrm{KCl}$ concentration was tested. $\mathrm{KCl}$ remained in contact with the preparation until the plateau of contraction was reached and after reaching the plateau the tissue was washed. After further 5 min the process was repeated and the cumulative concentration-response curve to pinacidil was obtained by adding increasing logarithmic molar concentrations (10 nM $0.1 \mathrm{mM}$ ). Subsequent concentrations were added to the organ bath after the previous concentration had produced its equilibrium response or after $10 \mathrm{~min}$ if no response was obtained. Relaxation produced by each concentration of pinacidil was measured and expressed as a percentage of the maximum possible relaxation (i.e., relaxation back to the baseline tension). Experiments followed the multiple curve design. The strips were washed and allowed to return to control contractions elicited by $\mathrm{KCl}$.

In separate experiments, after twitch responses became consistent, glibenclamide was added into the bathing solution, at least 20 min before exposure to pinacidil. Pinacidil was reintroduced into the bath and the concentration-effect values were obtained by the same procedure as before.

Vehicle- and time-matched control experiments were done. 
Acta Veterinaria (Beograd), Vol. 61, No. 2-3, 133-140, 2011.

Drugs and solutions

The following drugs were used: pinacidil monohydrate (Leo Pharmaceuticals) and glibenclamide, $\mathrm{KCl}$ (Sigma Chemical Co., St. Louis, MO, USA). Stock solution of pinacidil was dissolved in dilute acid solution $(0.1 \mathrm{~N} \mathrm{HCl})$ to make a stock solution of $100 \mu \mathrm{M}$ with a further dilution in PSS. Glibenclamide was dissolved in polyethylene glycol. $\mathrm{KCl}$ was dissolved in distilled water. Where $\mathrm{KCl}$ was used as the spasmogen the stated concentration excludes $\mathrm{KCl}$ present in PSS. PSS had the following composition (in $\mathrm{mM}$ ): $\mathrm{NaCl} 137, \mathrm{KCl} 5.36$, $\mathrm{CaCl}_{2} \cdot 2 \mathrm{H}_{2} \mathrm{O} 0.41, \mathrm{MgCl}_{2} \cdot 6 \mathrm{H}_{2} \mathrm{O} 0.19, \mathrm{Na}_{2} \mathrm{HPO}_{4} 0.36, \mathrm{NaHCO}_{3} 11.9$ and glucose 5.04. All drugs were added directly to the bath in a volume of $100 \mu \mathrm{L}$ and the concentrations given are the calculated final concentrations in the bath solution.

\section{Analysis of data}

$\mathrm{EC}_{50}$ value is defined as the concentration of pinacidil required to produce $50 \%$ of the maximum response of $\mathrm{KCl}$-elicited contractions, and it was determined for each curve by using a non-linear least square fitting procedure of the individual experimental data, and presented as $\mathrm{pD}_{2}\left(\mathrm{pD}_{2}=-\log \mathrm{EC}_{50}\right)$. The results are expressed as the mean \pm standard error of the mean (S.E.M.); $n$ refers to the number of trials. Statistical difference between means was determined by oneway ANOVA and Student's $t$-test, a value of $p<0.05$ was considered statistically significant. All calculations were done by using the computer program Graph Pad Prism (Graph Pad Software Inc., San Diego, USA).

\section{RESULT}

Application of $\mathrm{KCl}(20,40,80 \mathrm{mM})$ caused a rapid, phasic contraction followed by a prolonged sustained plateau (tonic component) (Fig. 1A-C).

Pinacidil (10 $\mathrm{nM}-0.1 \mathrm{mM}$ ) significantly induced a concentration-dependent relaxation $(p<0.05)$ of the spasm evoked by $20 \mathrm{mM} \mathrm{KCl}$ with $\mathrm{pD}_{2}$ value of $6.57 \pm$ $0.2 \mu \mathrm{M}$ (maximal response $100 \pm 0 \%, \mathrm{n}=7$ ). Glibenclamide $(1-10 \mu \mathrm{M})$ produced a significant rightward shift $\left(\mathrm{pD}_{2}\right.$ value of $5.68 \pm 0.3$ in the presence of $10 \mu \mathrm{M}$ glibenclamide, $p<0.01, n=5$ ) of the concentration-response curve to pinacidil in a concentration-dependent manner, without suppression of the maximal response ( $p>0.05)$ (Fig. 2A).

Pinacidil $(10 \mathrm{nM}-0.1 \mathrm{mM})$ inhibited $\mathrm{KCl}(40,80 \mathrm{mM})$ induced contractions in a concentration-dependent manner with $\mathrm{pD}_{2}$ values of $5.11 \pm 0.2 \mu \mathrm{M}$ and $5.19 \pm$ $0.2 \mu \mathrm{M}$ respectively (maximal inhibition of $100 \pm 0 \%$ and $97.20 \pm 2.3 \%, n=5,6$ ). The administration of glibenclamide $(1-10 \mu \mathrm{M})$ did not produce a significant shift to the right $(p>0.05)$ of the concentration-response curve for pinacidil $\left(\mathrm{pD}_{2}\right.$ values: $5.40 \pm 0.2 \mu \mathrm{M}$ in the presence $10 \mu \mathrm{M}$ glibenclamide on $40 \mathrm{mM} \mathrm{KCl}$-elicited contractions, and $5.26 \pm 0.5 \mu \mathrm{M}$ on $80 \mathrm{mM} \mathrm{KCl}$-elicited contractions, respectively, $\mathrm{p}>0.05, \mathrm{n}=7,8$ ) (Fig. 2B, 2C). 

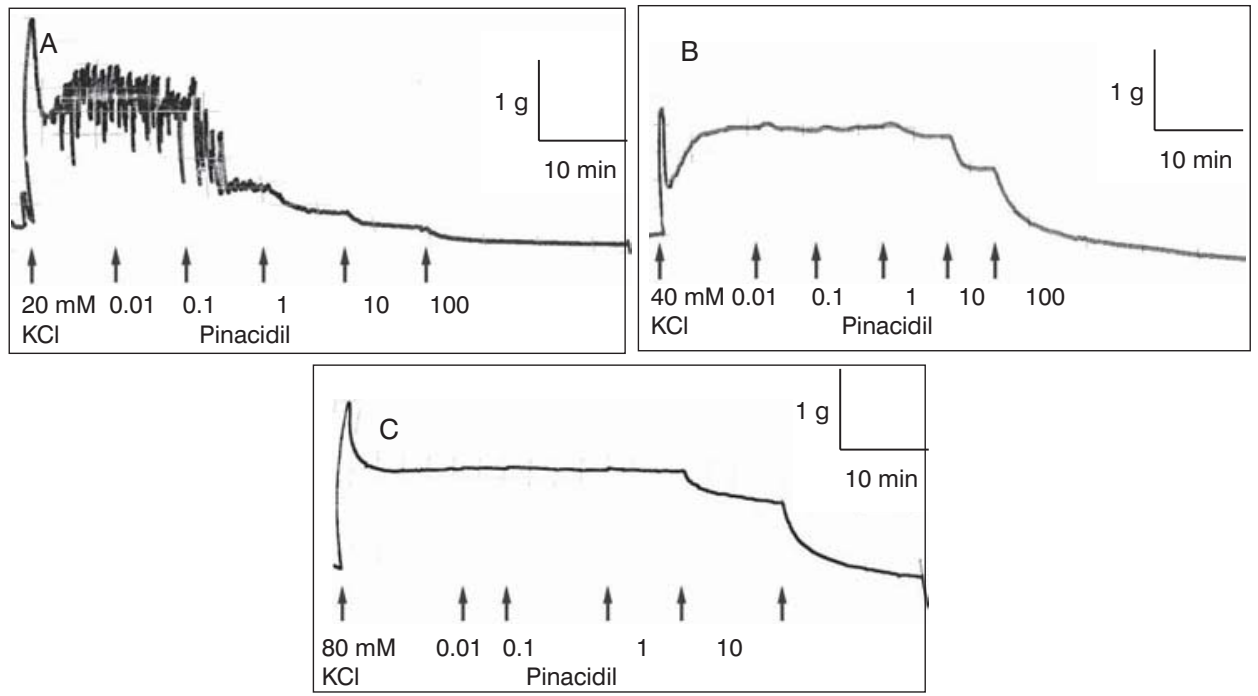

Figure 1. Original recordings show the typical effects of pinacidil on contractile activity of the non-pregnant rat myometrium: (A) contractions provoked by $20 \mathrm{mMKCl}$; (B) contractions provoked by $40 \mathrm{mM} \mathrm{KCl}$; (C) contractions provoked by $80 \mathrm{mM} \mathrm{KCl}$. The concentration of pinacidil is expressed as $\mu \mathrm{M}$
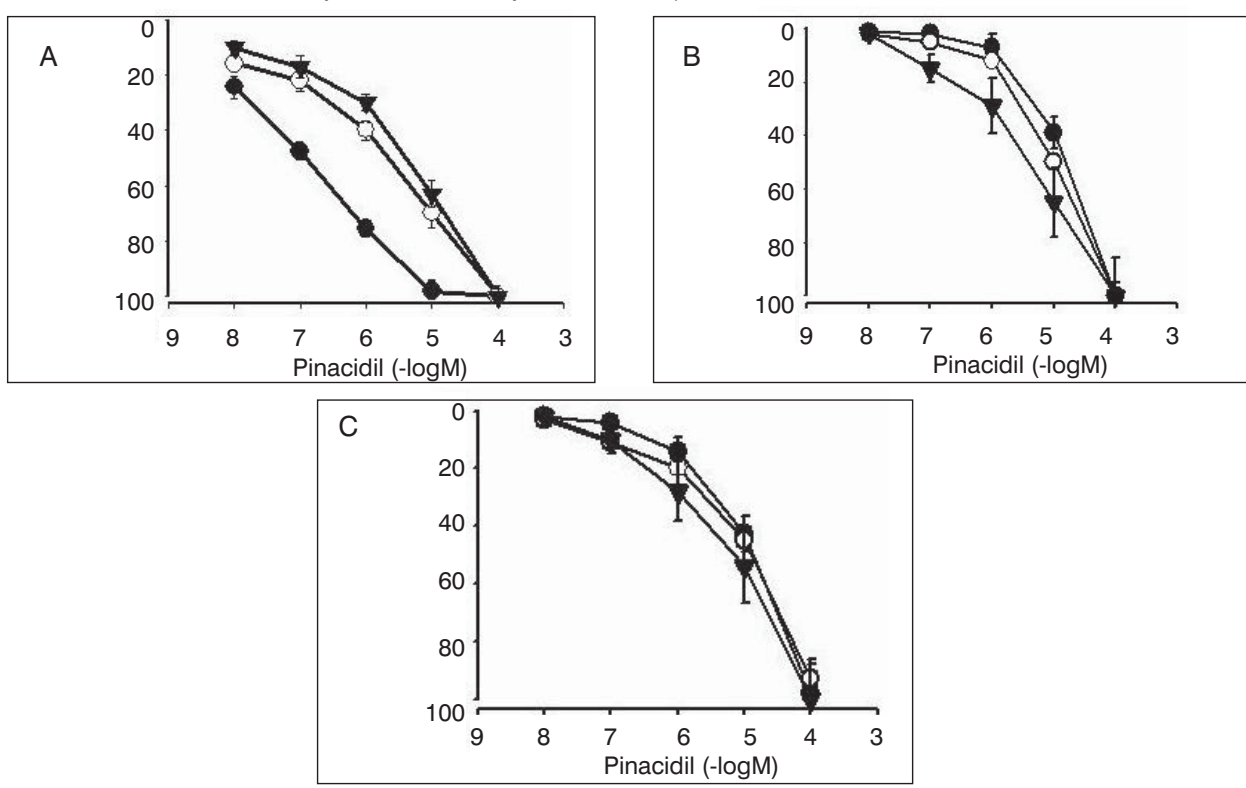

Figure 2. Effect of pinacidil on tension development in the isolated uterus of the nonpregnant rat treated with $\mathrm{KCl} 20 \mathrm{mM}(\mathrm{A}), 40 \mathrm{mM}(\mathrm{B}), 80 \mathrm{mM}(\mathrm{C})$. Effects are shown in the absence $(\bullet)$ and in presence of glibenclamide $(1 \mu \mathrm{M}, 0 ; 10 \mu \mathrm{M} \nabla)$. Responses are expressed as a percentage of the maximum possible relaxation. The points are the means and the vertical lines show the s.e.means $(n=7-10)$ 
Glibenclamide $(10 \mu \mathrm{M})$ had no effect on the resting tone of the preparations or on contractions elicited by $\mathrm{KCl}$ (percent of contractions were: $105.0 \pm 8.8 \%$ in the absence and $104.6 \pm 10.5 \%$ in the presence of glibenclamide, $p>0.05, n=4$, data not shown).

\section{DISCUSSION}

Pinacidil and other potassium channel openers open $\mathrm{K}^{+}$channels, hyperpolarize the membrane, inhibit $\mathrm{Ca}^{2+}$ influx, decrease cytosolic $\mathrm{Ca}^{2+}$ level and inhibit contractions (Gojkovic-Bukarica et al., 2010; Itoh et al., 1995; Novakovic et al., 2007). In opposite, all spasmogenic response to $\mathrm{KCl}$ can be explained by $\mathrm{Ca}^{2+}$ influx through voltage-dependent $\mathrm{Ca}^{2+}$ channels (Edvards et al., 1986). In the present study we partly confiremed former reports.

Pinacidil inhibits $20 \mathrm{mM} \mathrm{KCl-elicited} \mathrm{contractions} \mathrm{of} \mathrm{smooth} \mathrm{muscles} \mathrm{of} \mathrm{the}$ rat uterus in a concentration-dependent manner with a potency $\mathrm{pD}_{2}=6.57$. This value is higher then obtained for the canine mesenteric artery (5.88; Masuzawa et al., 1990) and is similar to those reported for the intestinal smooth muscle (6.19; Davies et al., 1996) and guinea-pig pulmonary artery (6.12; Eltze, 1989). Addition of $20 \mathrm{mM} \mathrm{KCl}$ to the extracellular compartment, giving rise to an extracellular potassium concentration that would result in increasing the membrane potential $(-59$ to $-46 \mathrm{mV}$ ) (Morrison et al., 1993). Accordingly, it may be concluded that $20 \mathrm{mM} \mathrm{KCl}$ induced membrane depolarisation increased $\left[\mathrm{Ca}^{2+}\right]_{\mathrm{i}}$ (Trujillo et al., 2000) whereas membrane hyperpolarization induced by pinacidil decreased the $\left[\mathrm{Ca}^{2+}\right]_{\mathrm{i}}$ available for contraction (Wray et al., 2007).

Glibenclamide is a well documented and potent blocker of the $\mathrm{K}_{\text {ATP }}$ channel and a large number of pharmacological studies have involved the use of glibenclamide to antagonize the relaxant effects of $\mathrm{K}^{+}$channel openers (Jovanovic et al., 1994). In the present study glibenclamide was found to produce a significant rightward shift in a concentration-dependent manner, with no suppression of the maximum of the concentration-response curves for pinacidil. The obtained affinity of glibenclamide indicates that pinacidil has an action involving glibenclamide-sensitive, $\mathrm{K}_{\text {ATP }}$ channel in rat uterus.

It has been shown that the equilibrium potential for potassium $(-31 \mathrm{mV})$ could be obtained by addition of $\geq 40 \mathrm{mM} \mathrm{KCl}$ (Morrison et al., 1993). Unexpectedly, pinacidil reduces uterine spasm elicited by 40 and $80 \mathrm{mM} \mathrm{KCl}$ concentrations with low potency $(5.11,5.19)$ suggesting a mechanism of action other than $\mathrm{K}^{+}$channel opening. Similar data is published for rat uterus (Piper et al., 1990), canine mesenteric artery (Masuzawa et al., 1990), rabbit aorta (Cook, 1989), guinea-pig trachea (Nielsen-Kudsk, 1988) and for the human internal mammary artery (Gojkovic et al., 1997). In contrast, it has been shown that in the human non-pregnant (Kostrzewska et al., 1996) and pregnant myometrium (Morrison et al., 1993) pinacidil did not inhibit contractions provoked by high $\mathrm{K}^{+}$ (>40 mM). The reason for this might be the lower concentrations of pinacidil $(0.01-10 \mu \mathrm{M})$ used in this study. The fact that glibenclamide $(10 \mu \mathrm{M})$ was unable to prevent the inhibition of $\mathrm{KCl}$ contractions $(>40 \mathrm{mM}$ ) induced by $100 \mu \mathrm{M}$ of 
pinacidil indicated the presence of an additional $\mathrm{K}_{\text {ATP }}$ channel - independent mechanism(s) of pinacidil action. Previously it has been showed on vascular smooth muscle that relaxant response to pinacidil have multiple sites of action: indirecly by reducing neurotransmitter release (Quast, 1993), by interaction with intracellular $\mathrm{Ca}^{2+}$ stores (Erne and Hermsmeyer, 1991; Greenwood and Weston, 1993), by inhibition of the receptor - mediated GTP binding protein - coupled $\mathrm{Ca}^{2+}$ sensitization (Anabuki et al., 1990), by inhibition of inositol-1,4,5-triphosphate $\left(\mathrm{IP}_{3}\right)$ syntheses (Itho et al., 1990). Interestingly, Trujillo et al. (2000) showed in the rat uterus, that high $\mathrm{K}^{+}$solutions in addition to their well known effect on $\mathrm{Ca}^{2+}$ influx, activate other cellular processes like increased total $\mathrm{IP}_{3}$ acumulation. This is in agreement with the present results and suggest that pinacidil has dual effects on rat uterine smooth muscle contractions: to decrease intracellular $\mathrm{Ca}^{2+}$ by activating $\mathrm{K}^{+}$channels and perhaps decrease $\mathrm{IP}_{3}$ syntheses. Thus, the relaxation of uterine smooth muscle related to reduction of intracellular $\mathrm{Ca}^{2+}$ produced by pinacidil is due to hyperpolarization of the plasma membrane resulting in not only the closure of voltage-dependent $\mathrm{Ca}^{2+}$ channels, but also in the inhibition of production of $\mathrm{IP}_{3}$ and $\mathrm{Ca}^{2+}$ release from intracellular stores.

The present data show that pinacidil exhibits potent relaxant properties in the rat non - pregnant uterus in oestrus and confirm the possibility that this agent may possess therapeutic potential in the treatment of motility disorders. Further, the results on the basis of glibenclamide affinity, are consistent with the existence of a glibenclamide - sensitive $\mathrm{K}_{\text {ATP }}$ channel in the rat uterus. The observations that pinacidil has additional, $\mathrm{K}^{+}$channel-independent mechanism(s) of action on contractions elicited by high $\mathrm{K}^{+}$solutions, need further evaluation.

\section{ACKNOWLEDGEMENTS:}

We would like to thank Mrs. Milena Zabunovic for technical support during this study. Our work has been supported by a Scientific Research Grant, project No TP 20027 from Ministry of Science and Technology, Serbia.

\section{Address for correspondence:}

Ljiljana Gojkovic-Bukarica, M.D., PhD, Associate Professor of Pharmacology Department of Clinical Pharmacology, Pharmacology and Toxicology

School of Medicine, University of Belgrade 11129 Belgrade, Serbia

E-mail: bukarica@rcub.bg.ac.rs

\section{REFERENCES}

1. Anabuki J, Hori M, Ozaki H, Kato I, Karaki H, 1990, Mechanisms of pinacidil-induced vasodilatation, Eur J Pharmacol, 190, 3, 373-9.

2. Bray KM, Newgreen DT, Small RC, Southerton JS, Taylor SG, Weir SW et al., 1987, Evidence that the mechanism of the inhibitory action of pinacidil in rat and guinea-pig smooth muscle differs from that glyceril trinitrate, Br J Pharmacol, 91, 421-29.

3. Cook NS, 1989, Effect of some potassium channel blockers on contractile responses of the rabbit aorta, J Cardiovasc Pharmacol, 13, 2, 299-306.

4. Davies M, McCurrie JR, Wood D, 1996, Comparative effects of $\mathrm{K}^{+}$channel modulating agents on contractions of rat intestinal smooth muscle, Eur J Pharmacol, 297, 3, 249-56. 
5. Edwards D, Good DM, Granger SE, Hollingsworth M, Robson A, Small RC et al., 1986, The spasmogenic action of oxytocin in the rat uterus - comparison with other agonists, $\mathrm{Br} \mathrm{J}$ Pharmacol, 88, 4, 899-908.

6. Eltze $M, 1989$, Glibenclamide is a competitive antagonist of cromakalim, pinacidil and RP 49356 in guinea-pig pulmonary artery, Eur J Pharmacol, 20, 165, 2-3, 231-9.

7. Erne P, Hermsmeyer K, 1991, Modulation of intracellular calcium by potassium channel openers in vascular muscle, Naunyn Schmiedebergs Arch Pharmacol, 344, 6, 706-15.

8. Gojkovic-Bukarica L, Kazic T, 1999, Differential effects of pinacidil and levcromakalim on the contractions elicited electrically or by noradrenaline in the portal vein of the rabbit, Fundam Clin Pharmacol, 13, 5, 527-34.

9. Gojkovic-Bukarica L, Kazic T, Sajic Z, Djukanovic B, Panic G, Peric M et al., 1997, The effects of levcromakalim and pinacidil on the human internal mammary artery, Fundam Clin Pharmacol, 11, 550-60.

10. Greenwood IA, Weston $A H, 1993$, Effects of rubidium on responses to potassium channel openers in rat isolated aorta, Br J Pharmacol, 109, 4, 925-32.

11. Granger SE, Hollingsworth M, Weston AH, 1985, A comparison of several calcium antagonists on uterine, vascular and cardiac muscles from the rat, $\mathrm{Br} J$ Pharmacol, 85, 1, 255-62.

12. Hughes SJ, Hollingsworth M, 1995, Cellular localization of the inhibitory action of relaxin against uterine spasm, Br J Pharmacol, 116, 7, 3028-34.

13. Itoh T, Suzuki S, Kuriyama $H$, 1991, Effects of pinacidil on contractile proteins in high $\mathrm{K}^{+}$-treated skinned smooth muscle of the rabbit mesenteric artery, Br J Pharmacol, 103, 1697-702.

14. Itoh T, Seki N, Suzuki S, Ito S, Kajikuri J, Kuriyama H, 1992, Membrane hyperpolarization inhibits agonist-induced synthesis of inositol 1,4,5-triphosphate in rabbit mesenteric artery, $J$ Physiol (Lond), 541, 307-28.

15. Jovanovic A, Gojkovic LJ, Kazic T, Grbovic L, Tulic I, 1994, Relaxation of human uterine artery in response to pinacidil: predominant role for ATP-dependent potassium channels, Arch Int Pharmacodyn Ther, 327, 344-54.

16. Khan RN, Morrison JJ, Smith SK, Ashford ML, 1998, Activation of large-conductance potassium channels in pregnant human myometrium by pinacidil, Am J Obstet Gynecol, 178, 5, 1027-34.

17. Kostrzewska A, Laudanski T, Batra S, 1996, Inhibition of contractile responses of human myometrium and intramyometrial arteries by potassium channel openers, Acta Obstet Gynecol Scand, 75, 10, 886-91.

18. Mandi G, Sarkar SN, Mishra SK, Raviprakash V, 2005, Effects of calcium channel blocker, mibefradil, and potassium channel opener, pinacidil, on the contractile response of midpregnant goat myometrium, Indian J Exp Biol, 43, 9, 795-801.

19. Masuzawa K, Matsuda T, Asano M, 1990, Evidence that pinacidil may promote the opening of ATPsensitive $\mathrm{K}+$ channels yet inhibit the opening of $\mathrm{Ca} 2(+)$-activated $\mathrm{K}+$ channels in $\mathrm{K}(+)$ contracted canine mesenteric artery, Br J Pharmacol, 100, 1, 143-9.

20. Morrison JJ, Ashford ML, Khan RN, Smith SK, 1993, The effects of potassium channel openers on isolated pregnant human myometrium before and after the onset of labor: potential for tocolysis, Am J Obstet Gynecol, 169, 5, 1277-85.

21. Nielsen-Kudsk JE, Mellemkjaer S, Siggaard C, Nielsen CB, 1988, Effects of pinacidil on guinea-pig airway smooth muscle contracted by asthma mediators, Eur J Pharmacol, 157, 2-3, 221-6.

22. Novakovic R, Milovanovic S, Protic D, Djokic J, Heinle H, Gojkovic-Bukarica L, 2007, The effect of potassium channel opener pinacidil on the non-pregnant rat uterus, Basic Clin Pharmacol Toxicol, 101, 3, 181-6.

23. Piper I, Minshall E, Downing JS, Hollingsworth M, Sadraei H, 1990, Effects of several potassium channel openers and glibenclamide on the uterus of the rat, Br J Pharmacol, 101, 901-7.

24. Quast U, 1993, Do the $\mathrm{K}^{+}$channel openers relax smooth muscle by opening $\mathrm{K}^{+}$channels? Trends Pharmacol Sci, 14, 332-7.

25. Trujillo MM, Ausina P, Savineau JP, Marthan R, Strippoli G, Advenier C et al., 2000, Cellular mechanisms involved in iso-osmotic high $\mathrm{K}+$ solutions-induced contraction of the estrogenprimed rat myometrium, Life Sci, 66, 25, 2441-53. 
26. Wray S, Jones K, Kupittayanant S, Li Y, Matthew A, Monir-Bishty E et al., 2003, Calcium signaling and uterine contractility, J Soc Gynecol Investig, 10, 5, 252-64.

\title{
EFEKTI PINACIDILA - OTVARAČA KALIJUMOVIH KANALA NA KONTRAKCIJE IZOLOVANOG NEGRAVIDNOG UTERUSA PACOVA IZAZVANE KALIJUM HLORIDOM
}

\author{
NOVAKOVIĆ RADMILA, MILOVANOVIĆ S, ĆUPIĆ V i GOJKOVIĆ-BUKARICA LJILJANA
}

\section{SADRŽAJ}

U ovom radu su prikazani efekti pinacidila, koji ima osobinu da otvara kalijumove kanale, na kontrakcije izazvane kalijum hloridom na modelu izolovanog negravidnog uterusa ženki pacova tokom estrusa. Pinacidil dovodi do snažnije inhibicije kontrakcija izazvanih sa $20 \mathrm{mM} \mathrm{KCl}\left(\mathrm{pD}_{2}=6.57 \mu \mathrm{M}\right)$ u poređenju sa kontrakcijama izazvanim sa 40 ili $80 \mathrm{mM} \mathrm{KCl}\left(\mathrm{pD}_{2}=5.11\right.$ i $\left.5.19 \mu \mathrm{M}\right)$. Poznato je da je glibenclamid selektivni blokator adenozin-3-fosfat senzitivnih $\mathrm{K}^{+}\left(\mathrm{K}_{\mathrm{ATP}}\right)$ kanala antagonizuje pinacidilom indukovanu kompetitivnu inhibiciju kontrakcija izazvanih pomoću $20 \mathrm{mM} \mathrm{KCl}$-a. Međutim, pinacidilom indukovana inhibicija kontrakcija, izazvanih sa 40 i $80 \mathrm{mM} \mathrm{KCl}$-a nije se mogla prevenirati glibenclamidom. Sposobnost pinacidila da dovede do potpune relaksacije negravidnog uterusa ženki pacova pre kontrakcije izazvane rastvorom kalijuma ukazuje na to da u relaksaciji učestvuje i mehanizam nezavisan od kalijumovih kanala. 